\title{
Clinicohistopathological and Immunological Alterations in Egyptian Donkeys Infested by Rhinoestrus Spp. During the Winter Season
}

\author{
Faten A.M. Abo-Aziza*, Seham H.M. Hendawy*, Zaki A.A. **, Samah S. Oda*** and \\ Amira H. El-Namaky* \\ *Department of Parasitology and Animal Diseases, Veterinary Research Division, National \\ Research Centre, **Department of Physiology, Faculty of Veterinary Medicine, Cairo \\ University, and ***Department of Pathology, Faculty of Veterinary Medicine, Alexandria \\ University, Edfina, Egypt.
}

\begin{abstract}
ITTLE information is available about the homeostasis and alterations appeared against Uinfestation by nasal myiasis caused by Rhinoestrus spp. larvae inEgyptiandonkeys. Therefore, the present work aimed to investigate the hematological and biochemical profiles associated with histopathological features and immunological response developed against Rhinoestrus spp. larvae infestation in donkeys in the winter season. The results revealed that 40 out of 80 examined donkeys were infested bynasal myiasis. IgG values were higher $(\mathrm{P}<0.01)$ in infested donkeys (IND) than non-infested ones all over the winter months while the highest mean larval burden was observed in December (11.6 larvae/animal). Neutrophils\% in (IND) increased $(P<0.01)$ during December and February. However, an elevation in lymphocytes\% $(P<0.05)$ was observedin (IND) during Decemberand Januarywhile eosinophils\% increased $(P<0.01)$ in all winter months. These results paralleled to the nasal fluid cytological profile in which lymphocytes \%, neutrophils\% and eosinophils\% in (IND) increased $(P<0.05)$ in December, January and February.Glutathione peroxidase, superoxide dismutase and catalase activities in (IND) were declined $(P<0.01)$ in all winter months. Interleukin-2 (IL-2)and tumor necrosis factor- $\alpha(\mathrm{TNF}-\alpha)$ elevated $(P<0.05)$ in December and January. The histopathological picture of turbinate bones, olfactory bulb and meninges reflected the blood and nasal fluid cytological picture as there were lymphocytes infiltration, meningitis and satellitosis. The results indicated that Rhinoestrus spp. infestation in donkeys might affect the vital and immunological processes. In addition, Rhinoestrus spp. infestation in donkeys could linked to oxidative stress and shifting the immune response polarization towards Th2 cytokines.
\end{abstract}

Keywords: Rhinoestrusspp, Clinicohistopathological, Cytokines, Antioxidant, Donkeys.

\section{Introduction}

Rhinoestrosis is a nasal bot myiasis caused by larvae of Rhinoestrus spp (Diptera: Oestridae) and occurs worldwide in both developing and developed countries [1]. Larvae are deposited by adult fly into host's nostrils. The first instar larvae developed into the second instar and then third instar larvae habituated at the nasal cavities, sinuses and pharynx of equids. Their maturation depends on the climatic conditions thus, it is almost impossible to generalize the timing of the life cycle of Rhinoestrus spp [2]. Pathogenesis of rhinoestrosis varied from asymptomatic to death of horses and donkeys. These larvae cause traumatic irritation to mucus membrane of nasal cavities and sinuses due to its creeping and cuticle's spines. In addition, damages to olfactory nerve and encephalomyelitis occur due to penetration of the larvae in the ethmoid and meninges [3]. This affection may induce local inflammation and causes clinical signs of varying intensity and severity ranging from inflammation to dyspnea, sneezing and cough [2].

Infestations by these larvae stimulate defense immune mechanism strategies to survive with host's humoral and cell mediated immune responses. This immune response efficiency depends on health, physiological and nutritional status of animal beside site of parasitism and nature of antigenic determents to recall immunological defense mechanisms [2]. Infiltration of inflammatory cells (mast cells, 
eosinophils and macrophages) and secretions of immunoglobulin, T- helper1 (Th1) and Thelper2 (Th2) are characteristic of Oestridae nasal bot larvae infestations [4]. Diagnosis of such myiasis is very difficult in live animals. It usually depends on parasitological detection of infested larvae at post-mortem examination [5]. Previous literatures about life cycle, seasonal variations of Rhinoestrus spp [6] and characterization of different antigens of Rhinoestrus spp [1,7] were studied. However, little information is available about the host immune response and alterations appeared against Rhinoestrus spp. Larvae.

Hence, the present work aimed to investigate IgG and cytokines immune response combined with hematological profile and pathological features developed against Rhinoestrus spp larvae for understanding its chronobiology, which will help in planning the critical period for its diagnosis, treatment and control.

\section{Material and Methods}

Animals and sampling

This study was conducted in the winter season, starting from December 2015 to March 2016 at temperature ranged from $12-18^{\circ} \mathrm{C}$ and relative humidity $(\mathrm{RH})$ varied from $40-60 \%$. The samples were collected from 80 working donkeys after slaughtering at zoo abattoir (Giza, Egypt) in winter season (December 2015 to March 2016) with average 3 visits/month. The donkeys were brought to the Zoo from Fayoum, Beni-Suef and Monofia governorates according to the general administration of the Zoo. Before slaughtering, the nasal fluid was collected from each animal according to Zhang et al. [8]. Briefly, a syringe containing $10 \mathrm{ml}$ PBS (pH 7.2) was flushed into the nasal cavity and quickly suctioned or "re-aspirated" back into the syringe. The reaspirated fluid contains lining cells, secretions and other material that has been "washed off" by the flushing action to be exposed to the cytological examination. Blood samples of slaughtered donkeys were collected immediately after slaughter. Half of the blood sample was taken into EDTA containing vacutainer tubes for hematological study. The other half was maintained in plain tubes and allowed to clot for serum extraction then divided in small aliquots and stored at $-20^{\circ} \mathrm{C}$ for immunological and biochemical assays. The corresponding heads of the slaughtered donkeys were longitudinally cut and examined by naked eyes for the presence of
R.purpureus larvae. Larvae of each head were collected and separately placed in vial and then transported to the laboratory for identification. Corresponding tissue specimens from turbinate bones, olfactory bulb, meninges and brains were collected from all slaughtered donkeys for histopathological examination.

\section{Identification of Rhinoestrus spp larvae}

All collected larvae were washed in phosphate buffer saline (PBS, 7.2 pH) and microscopically identified into L1, L2 and L3 of Rhinoestrus spp larvae [9].

\section{Specific IgG response}

The specific IgG humoral immune response developed against Rhinoestrusspp was estimated in collected sera by using indirect ELISA according to Angulo-Valadez et al. [10]. Crude $2^{\text {nd }}$ larva of Rhinoestrus spp antigen (CL2A) was prepared as described by Tabouret et al. [11]. The protein concentration was measured [12]. A concentration of $6 \mu \mathrm{g} /$ well of obtained CL2A was used. The optical densities (OD) were read at 450nm using an ELISA reader (BIO-TEK, INC., ELx, 800UV). Ten positive and eight negative control sera were obtained from infested donkeys and non-infested foals, respectively. The cut-off value was calculated from mean OD values of negative control sera plus three-fold standard deviations. Sensitivity and specificity of CL2A were determined [11].

\section{Hematological studies}

Total erythrocytes and total leukocytes (TLC) were counted. The blood samples were analyzed for hemoglobin $(\mathrm{Hb})$ and packed cell volume (PCV) determination [13]. Neutrophils, lymphocytes and eosinophils were estimated as cross sectional method [14].

\section{Cytological examination of nasal fluid}

To count the inflammatory cells in the nasal fluid, the method of Zhang et al. [7] was performed with some modifications. The collected nasal fluids were centrifuged at $3000 \mathrm{rpm}$ for $5 \mathrm{~min}$ then the precipitate was resuspended. The cell pellet was gently suspended in $200 \mu \mathrm{L}$ of PBS, and the suspension was enumerated microscopically in a Neubauer's chamber, discriminating leukocytes. Neutrophils, lymphocytes and eosinophils were estimated as cross sectional method.

Biochemical examination

Total protein was determined by coloremetric 
method (Biuret reagent) [15] using SPECTRUM kits (BioMerieux, SA). Albumin was determined by modified bromocresol green colorimetric method [16]using SPECTRUM kits (BioMerieux, $\mathrm{SA})$. Globulin and albumin globulin (A/G) ratio were calculated.

Interleukin-2 (IL-2) and Tumor necrosis factor alpha $(T N F-\alpha)$

IL-2 and TNF- $\alpha$ concentrations in serum samples were measured by an equine-specific ELISA kits (WKEA MED Supplies) according to the manufacturer's instructions using purified IL-2 and TNF- $\alpha$ antibodies respectively. The color change was measured spectrophotometrically at a wavelength of $450 \mathrm{~nm}$ and the concentration of IL-2 and TNF- $\alpha$ in the samples were determined by comparing the OD of the samples to the standard curve.

\section{Antioxidant activity}

Glutathione peroxidase (GSH-PX), superoxide dismutase (SOD) and catalase (CAT) activities in serum samples were measured using SPECTRUM kits (BioMerieux, SA). Absorbencies were measured at $340 \mathrm{~nm}, 560 \mathrm{~nm}$ and $520 \mathrm{~nm}$ respectively by spectrophotometer.

\section{Histopathological examination}

The collected tissue specimens from turbinate bones, olfactory bulb, meninges and brains were rapidly fixed in $10 \%$ neutral buffered formalin for at least 24 hours. Fixed specimens were dehydrated in ascending grades of ethyl alcohol, cleared in xylene, embedded in paraffin wax, sectioned at $4-5 \mu \mathrm{m}$ thickness then stained with hematoxylin and eosin (H\&E) [17].

\section{Statistical analysis}

The statistical analysis was conducted to determine the significance between infested donkeys by $R$. larvae and uninfested for all tested parameters. Therefore, the data were statistically analyzed by Student's t-test at level $P<0.05$ [18] using Statistical Package for Social Science (SPSS) for Windows version 15 computer program.

\section{$\underline{\text { Results }}$}

Intensity of the larval instars and serum $\operatorname{Ig} G$ response

During winter season, 40 out of $80(50 \%)$ examined donkeys were infested with one or more equine nasal bot (Rhinoestrusspp) larvae. A total number of 346 larvae were collected. The percentages of $1^{\text {st }}$ larva (L1), $2^{\text {nd }}$ larva (L2) and $3^{\text {rd }} \operatorname{larva}(\mathrm{L} 3)$ were notably varied as they were $95.45 \%, 23.4 \%$ and $3.75 \%$, respectively. The number of L1 and L2 recorded its highest intensity in January and March respectively. However, the number of L3 was very small and its highest value was observed in March (Table 1). ELISA detected IgG humoral immune response against Rhinoestrusspp using CL2A and the existence of larval instar of Rhinoestrus spp in the examined donkeys. The sensitivity of ELISA and specificity of CL2A were $97.5 \%$ and $47.5 \%$, respectively. IgG mean optical densities values of infested donkeys were higher all over the winter months $(P<0.01)$. The highest mean larval burden was recorded in December (11.6) while the lowest mean larval burden was detected in February (7.06) (Table 1).

TABLE 1. Infestation intensity of larval stages of Rhinoestrus spp in donkeys during winter months combined with IgG optical densities (OD).

\begin{tabular}{lcccccccc}
\hline \multirow{2}{*}{ Months } & \multicolumn{2}{c}{ December } & \multicolumn{2}{c}{ January } & \multicolumn{2}{c}{ February } & \multicolumn{2}{c}{ March } \\
\cline { 2 - 8 } & $\begin{array}{c}\text { Non- } \\
\text { infested }\end{array}$ & Infested & $\begin{array}{c}\text { Non- } \\
\text { infested }\end{array}$ & Infested & $\begin{array}{c}\text { Non- } \\
\text { infested }\end{array}$ & Infested & $\begin{array}{c}\text { Non- } \\
\text { infested }\end{array}$ & Infested \\
\hline $\begin{array}{l}\text { No. of examined } \\
\text { donkeys }\end{array}$ & 15 & 5 & 9 & 11 & 2 & 16 & 14 & 8 \\
\hline $\begin{array}{l}\text { L1 Intensity of } \\
\text { larval stages }\end{array}$ & - & 56 & - & 110 & - & 82 & - & 4 \\
\hline $\begin{array}{l}\text { L2 Intensity of } \\
\text { larval stages }\end{array}$ & - & 2 & - & 7 & - & 29 & - & 43 \\
\hline $\begin{array}{l}\text { L3 Intensity of } \\
\text { larval stages }\end{array}$ & - & 0 & - & 0 & - & 2 & - & 11 \\
\hline $\begin{array}{l}\text { Mean larval } \\
\text { burden }\end{array}$ & - & 11.6 & - & 10.6 & - & 7.06 & - & 7.25 \\
\hline \begin{tabular}{l} 
IgG OD \\
\hline
\end{tabular} & 0.300 & $0.476^{* *}$ & 0.270 & $0.473^{* *}$ & 0.283 & $0.631^{* *}$ & 0.314 & $0.449^{* *}$ \\
\hline 0.01 & \pm 0.02 & \pm 0.06 & \pm 0.03 & \pm 0.03 & \pm 0.09 & \pm 0.05 & \pm 0.04 \\
\hline
\end{tabular}

Values have ** were significantly differ than the corresponding non-infested group at $\mathrm{P}<0.01$. 


\section{Haemogram and Leukogram}

Total erythrocytes of infested donkeys significantly decreased $(P<0.05)$ in December and January, while PCV\% significantly decreased $(P<0.05)$ in December comparing with non-infested donkeys (Table 2). However, neutrophils $\%$ of infested donkeys recorded a significant elevation during December $(P<0.01)$ and February $(P<0.05)$ while lymphocytes $\%$ increased $(P<0.05)$ in December and January. As well as, eosinophils\% of infested donkeys showed marked significant elevation $(P<0.01)$ in all winter months (Table 2).

\section{Cytological parameters of nasal fluid}

Table 3 shows the alteration in some cytological parameters of nasal fluid of Rhinoestrus spp infested donkeys comparing with non-infested donkeys during winter months. A significant decline $(P<0.05)$ in neutrophils\% in nasal fluid of infested donkeys was observed in December and significantly increased $(P<$ 0.05 ) in February. Lymphocytes\% in nasal fluid of infested donkeys decreased $(P<0.05)$ in December while increased $(P<0.05)$ in January and March. However, eosinophils \% in nasal fluid of infested donkeys increased significantly $(P<0.01)$ in December, February and March.

TABLE 2. The effect of Rhinoestrus spp infestation on blood haemogram and leukogram of donkeys during winter months.

\begin{tabular}{lcccccccc}
\hline \multirow{2}{*}{ Months } & \multicolumn{2}{c}{ December } & \multicolumn{2}{c}{ January } & \multicolumn{2}{c}{ February } & \multicolumn{2}{c}{ March } \\
\cline { 2 - 9 } & $\begin{array}{c}\text { Non- } \\
\text { infested }\end{array}$ & Infested & $\begin{array}{c}\text { Non- } \\
\text { infested }\end{array}$ & Infested & $\begin{array}{c}\text { Non- } \\
\text { infested }\end{array}$ & Infested & $\begin{array}{c}\text { Non- } \\
\text { infested }\end{array}$ & Infested \\
\hline Rbcs $\left(10^{6}\right.$ cells/ & 5.64 & $3.18^{*}$ & 5.92 & $3.72^{*}$ & 4.96 & 4.37 & 5.52 & 5.47 \\
$\left.\mathrm{~mm}^{3}\right)$ & \pm 0.82 & \pm 0.15 & \pm 1.37 & \pm 0.21 & \pm 1.12 & \pm 1.08 & \pm 1.08 & \pm 1.14 \\
\hline \multirow{2}{*}{$\mathrm{Hb}(\mathrm{gm} / \mathrm{dl})$} & 12.48 & 9.85 & 11.63 & 9.38 & 12.49 & 11.93 & 12.96 & 11.19 \\
& \pm 2.97 & \pm 1.68 & \pm 1.46 & \pm 2.10 & \pm 2.83 & \pm 1.57 & \pm 2.02 & \pm 2.82 \\
\hline \multirow{2}{*}{ PCV\% } & 39.23 & $30.44 *$ & 40.07 & 34.74 & 35.67 & 34.10 & 39.67 & 38.25 \\
& \pm 2.51 & \pm 2.81 & \pm 3.81 & \pm 2.46 & \pm 4.11 & \pm 5.23 & \pm 4.84 & \pm 4.62 \\
\hline \multirow{2}{*}{ Total leukocyte } & 7.43 & 8.65 & 7.26 & 8.34 & 8.11 & 7.39 & 7.40 & 7.01 \\
\hline \multirow{2}{*}{ Neutrophils\% } & \pm 1.98 & \pm 1.65 & \pm 1.76 & \pm 2.22 & \pm 2.55 & \pm 1.87 & \pm 1.09 & \pm 0.92 \\
\hline \multirow{2}{*}{ Lymphocytes\% } & 18.14 & $24.42^{* *}$ & 17.50 & 19.72 & 19.72 & $24.11 *$ & 15.66 & 19.53 \\
\hline \multirow{2}{*}{ Eosinophils\% } & \pm 1.023 & \pm 2.015 & \pm 2.41 & \pm 1.038 & \pm 2.17 & \pm 1.02 & \pm 3.030 & \pm 1.34 \\
\hline
\end{tabular}

Values have *, ** were significantly differ than the corresponding non-infested group at $\mathrm{P}<0.05$ and $\mathrm{P}<0.01$ respectively.

TABLE 3. The effect of Rhinoestrus spp larvae infestation on some cytological parameters of nasal fluid of donkeys during winter months.

\begin{tabular}{|c|c|c|c|c|c|c|c|c|}
\hline \multirow{2}{*}{ Parameters } & \multicolumn{2}{|c|}{ December } & \multicolumn{2}{|c|}{ January } & \multicolumn{2}{|c|}{ February } & \multicolumn{2}{|c|}{ March } \\
\hline & $\begin{array}{c}\text { Non- } \\
\text { infested }\end{array}$ & Infested & $\begin{array}{c}\text { Non- } \\
\text { infested }\end{array}$ & Infested & $\begin{array}{c}\text { Non- } \\
\text { infested }\end{array}$ & Infested & $\begin{array}{c}\text { Non- } \\
\text { infested }\end{array}$ & Infested \\
\hline Neutrophils\% & $\begin{array}{l}21.15 \\
\pm 1.02\end{array}$ & $\begin{array}{l}15.42 * \\
\pm 2.01\end{array}$ & $\begin{array}{l}16.60 \\
\pm 2.42\end{array}$ & $\begin{array}{l}14.72 \\
\pm 1.04\end{array}$ & $\begin{array}{l}15.72 \\
\pm 2.17\end{array}$ & $\begin{array}{c}20.11 * \\
\pm 1.02\end{array}$ & $\begin{array}{l}16.66 \\
\pm 3.03\end{array}$ & $\begin{array}{l}14.53 \\
\pm 1.14\end{array}$ \\
\hline Lymphocytes\% & $\begin{array}{l}63.22 \\
\pm 1.02 \\
\end{array}$ & $\begin{array}{l}57.59^{*} \\
\pm 2.033\end{array}$ & $\begin{array}{l}53.12 \\
\pm 1.13 \\
\end{array}$ & $\begin{array}{l}63.50 * \\
\pm 2.041 \\
\end{array}$ & $\begin{array}{l}58.13 \\
\pm 4.06 \\
\end{array}$ & $\begin{array}{c}60.72 \\
\pm 3.141 \\
\end{array}$ & $\begin{array}{l}57.65 \\
\pm 1.02 \\
\end{array}$ & $\begin{array}{l}68.44^{*} \\
\pm 2.035\end{array}$ \\
\hline Eosinophils\% & $\begin{array}{c}4.21 \\
\pm 0.85\end{array}$ & $\begin{array}{c}8.12 * * \\
\pm 1.01\end{array}$ & $\begin{array}{c}4.33 \\
\pm 1.03\end{array}$ & $\begin{array}{c}7.37 \\
\pm 1.03\end{array}$ & $\begin{array}{c}4.61 \\
\pm 1.02\end{array}$ & $\begin{array}{c}9.15^{* *} \\
\pm 1.07\end{array}$ & $\begin{array}{c}3.99 \\
\pm 0.81\end{array}$ & $\begin{array}{l}7.22 * \\
\pm 1.03\end{array}$ \\
\hline Monocytes\% & $\begin{array}{c}3.12 \\
\pm 0.84\end{array}$ & $\begin{array}{c}3.42 \\
\pm 0.63\end{array}$ & $\begin{array}{c}3.17 \\
\pm 0.94\end{array}$ & $\begin{array}{c}4.01 \\
\pm 0.98\end{array}$ & $\begin{array}{c}3.22 \\
\pm 0.27\end{array}$ & $\begin{array}{c}4.72 \\
\pm 0.52\end{array}$ & $\begin{array}{c}3.55 \\
\pm 0.13\end{array}$ & $\begin{array}{c}4.33 \\
\pm 1.41\end{array}$ \\
\hline
\end{tabular}

Values have *, ** were significantly differ than the corresponding non-infested group at $\mathrm{P}<0.05$ and $\mathrm{P}<0.01$ respectively.

Egypt. J. Vet. Sci. Vol. 48, No.2 (2017) 


\section{Biochemical studies}

Total protein concentrations in the serum of Rhinoestrus spp infested donkeys significantly decreased $(P<0.05)$ in February and March. However, albumin concentrations of the infested donkeys significantly decreased $(P<0.05)$ in February only while globulin concentrations significantly decreased $(P<0.01)$ in February and March. Sodium levels in serum of Rhinoestrus spp infested donkeys significantly decreased $(P<$ $0.05)$ in January, February and $\operatorname{March}(P<0.01)$. On the other hand, serum potassium levels of infested donkeys significantly increased $(P<$ $0.05)$ in December and February. However, calcium concentration in serum of Rhinoestrus spp infested donkeys significantly decreased $(P<$ $0.05)$ in January only comparing with the noninfested group (Table 4).

Antioxidant activity

Table 4 shows the changes in antioxidant activities of Rhinoestrus spp. infested donkeys during winter months.GSH $-\mathrm{PX}$ serum concentrations of infested donkeys significantly decreased $(P<0.01)$ in January, February and March. As well as, SOD significantly decreased $(P<0.05)$ in December, January and February. However, CAT significantly decreased $(P<0.05)$ in all the months of the study.

TABLE 4. The effect of Rhinoestrus spp larvae infestation on serum protein parameters, some electrolytes and glutathione peroxidase (GSH -PX -U/ml), superoxide dismutase (SOD- U/ml) and catalase (CAT - U/ ml) activity of donkeys during winter months.

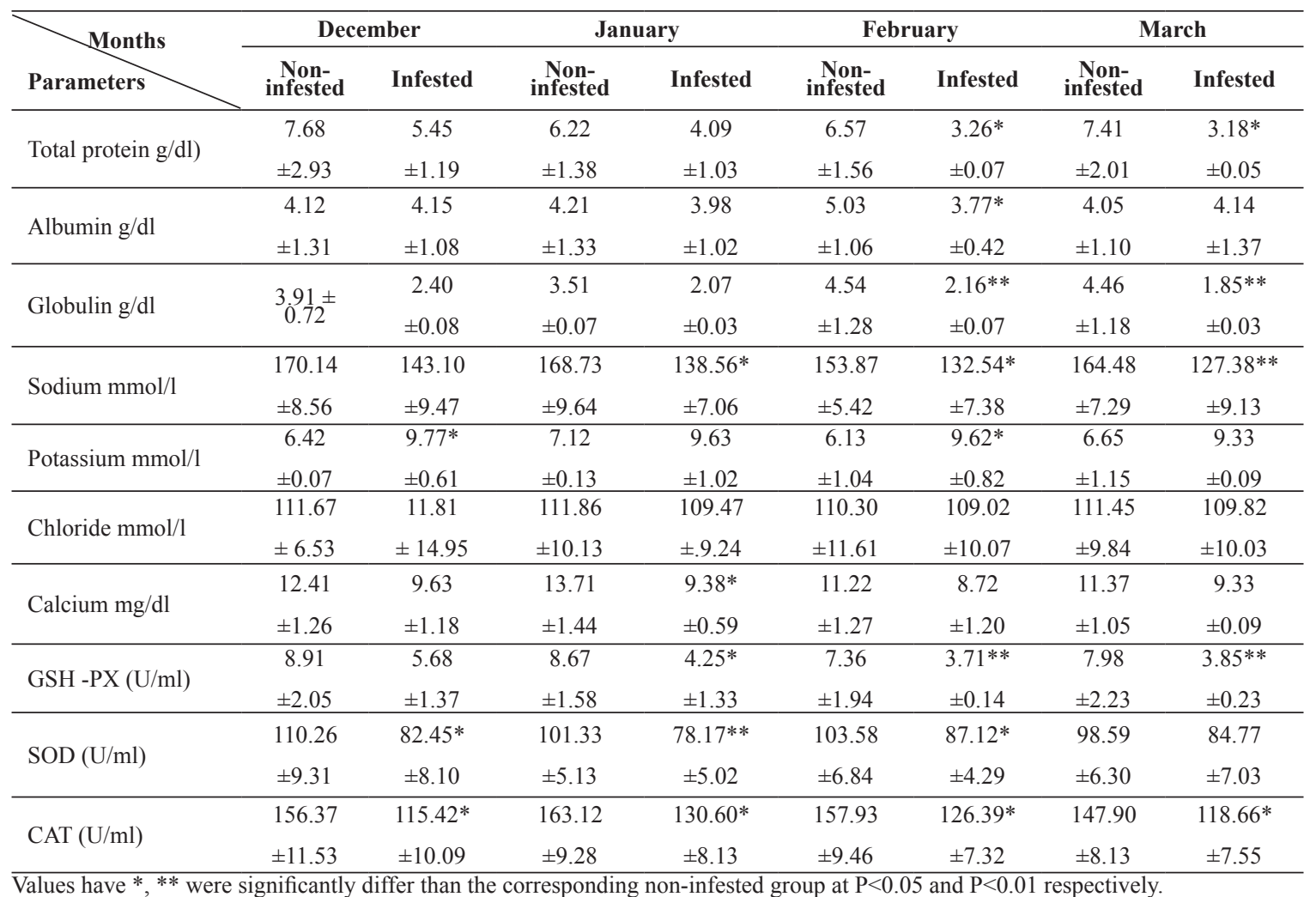

Interleukin-2 (IL-2) and Tumor necrosis factor alpha $(T N F-\alpha)$

Table 5 showed an increase $(P<0.05)$ in IL-2 in December, January $(P<0.01)$ and March while TNF- $\alpha$ increased $(P<0.05)$ in December and January.

\section{Histopathological results}

The turbinates' mucosae of Rhinoestrus- infested donkeys showed variable degrees of degenerative, necrotic and inflammatory changes. The picture of catarrhal rhinitis was evident. Hence, the mucosal epithelium was greatly thickened with moderate to severe goblet cell hyperplasia (Fig. 1A). Sometimes, there were atrophy and thinning of the mucosal epithelium with underlying inflammatory cell infiltrates and congestion(Fig. 1B). Focal to diffuse inflammatory Egypt. J. Vet. Sci. Vol. 48, No.2 (2017) 
cells infiltration, particularly macrophages, lymphocytes and eosinophils were evident in the mucosa and submucosa (Fig. 1C). Also, there was necrosis of mucosal epithelium besides mucosal ulceration. Chronic ulcers were covered by areas of squamous metaplasia with severe inflammatory cell infiltrates in the underlying mucosa and submucosa (Fig. 1D). Regarding to submucosal glands, there were epithelial degeneration and hyperplasia as well some glands were cystically dilated with presence of eosinophilic secretions
(Fig. 1E). Olfactory mucosa showed mononuclear cell infiltrates mainly lymphocytes in lamina propria (Fig. 1F). Moreover, mild to severe meningioencephalitis was recorded. As there were congestion and lymphocytic cell infiltrates in the meninges (Fig. 1G) and the cerebral cortex giving the characteristic lesion of perivascular cuffing (Fig. 1H). There were neuronal degenerative and necrotic changes with different glial cell reaction, particularly satellitosis and neuronophagia (Fig. 1I).

TABLE 5. Interleukin-2 (IL-2) and tumor necrosis factor alpha (TNF- $\alpha$ ) measurement in Rhinoestrus spp infected donkeys.

\begin{tabular}{ccccccccc}
\hline \multirow{2}{*}{ Months } & \multicolumn{2}{c}{ December } & \multicolumn{2}{c}{ January } & \multicolumn{2}{c}{ February } & \multicolumn{2}{c}{ March } \\
\cline { 2 - 9 } Parameters & $\begin{array}{c}\text { Non- } \\
\text { infested }\end{array}$ & Infested & $\begin{array}{c}\text { Non- } \\
\text { infested }\end{array}$ & Infested & $\begin{array}{c}\text { Non- } \\
\text { infested }\end{array}$ & Infested & $\begin{array}{c}\text { Non- } \\
\text { infested }\end{array}$ & Infested \\
\hline IL-2 & 8.84 & $13.57^{*}$ & 8.57 & $15.76^{* *}$ & 9.46 & 12.38 & 10.16 & $14.98^{*}$ \\
$(\mathrm{ng} / \mathrm{ml}$ & 1.05 & 1.18 & 1.93 & 1.27 & 1.03 & 1.93 & 0.75 & \pm 1.66 \\
\hline $\mathrm{TNF}-q(\mathrm{ng} /$ & 9.14 & $15.78^{*}$ & 10.35 & $16.05^{*}$ & 9.86 & 12.29 & 11.55 & 14.97 \\
$\mathrm{ml})$ & 1.58 & 1.15 & 1.31 & 1.41 & 1.27 & \pm 1.81 & 1.07 & \pm 1.26 \\
\hline
\end{tabular}

Values have *, ** were significantly differ than the corresponding non-infested group at $\mathrm{P}<0.05$ and $\mathrm{P}<0.01$ respectively.
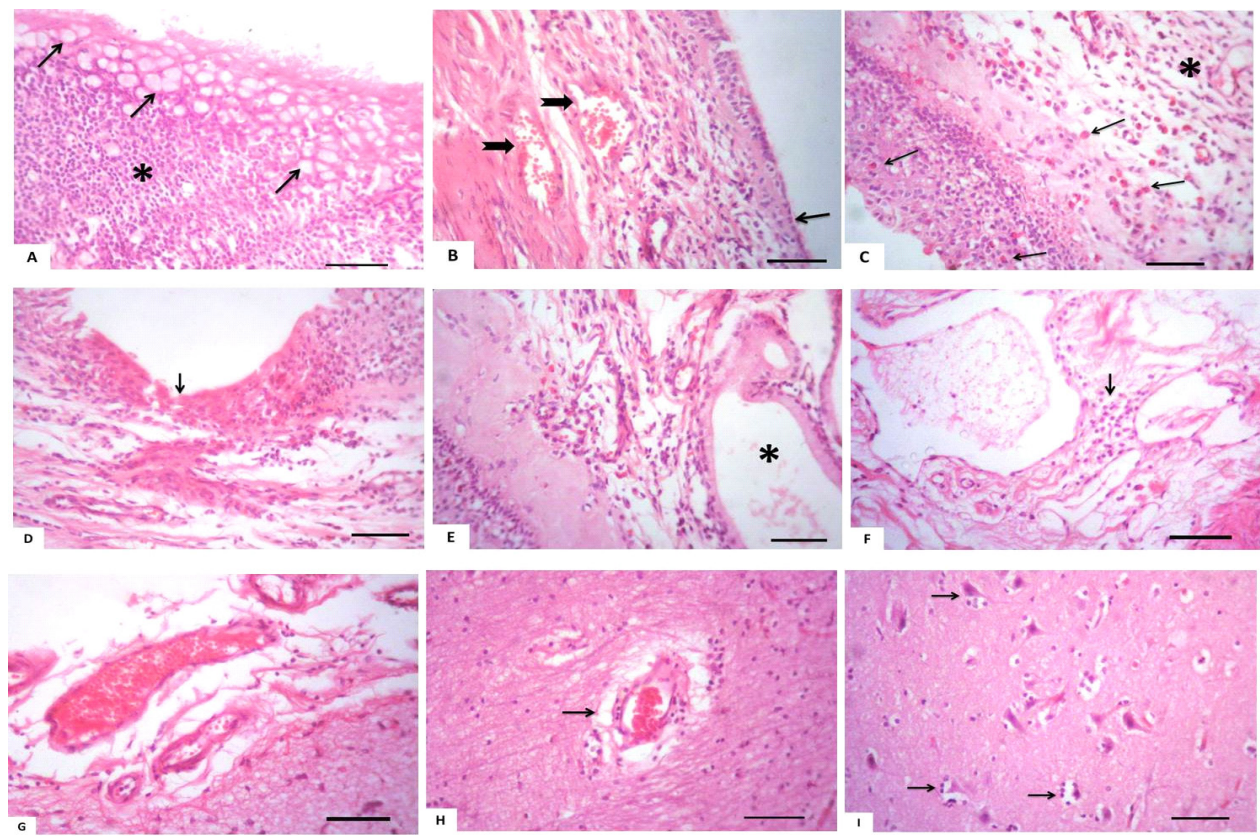

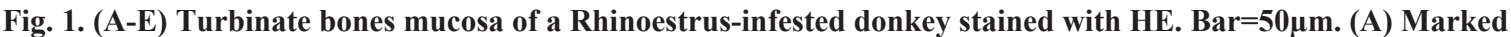
thickening of nasal mucosa (asterisk) with goblet cell hyperplasia (arrows). (B) Thinning of mucosal epithelium (arrow) with mucosal and submucosal congestion (notched arrows). (C) Marked thickening of mucosa and submucosa with inflammatory cells (asterisk) and infiltration of numerous eosinophils (arrows). (D) Mucosal ulceration covered by areas of squamous metaplasia (arrow) with mucosal and submucosal inflammatory cells infiltration. (E) Submucosal inflammatory cells infiltration with cystic dilatation of submucosal glands. (F) Olfactory mucosa of a Rhinoestrus-infested donkey stained with HE. Bar $=50 \mu \mathrm{m}$. Submucosal perivascular lymphocytic cell infiltration (arrow) with presence of fibrin admixed with inflammatory cells inside dilated blood vessel. (G) Meninges of a Rhinoestrus-infested donkey stained with HE. Bar=50 $\mu \mathrm{m}$. congestion of meningeal blood vessels with few lymphocytic cell infiltration. (H-I) Cerebral cortex of a Rhinoestrus-infested donkey stained with HE. Bar=50 $\mu \mathrm{m}$. (H) Lymphocytic perivascular cuffing (arrow). (I) Shrunken neurons with glial cell reaction, particularly satellitosis (arrows).

Egypt. J. Vet. Sci. Vol. 48, No.2 (2017) 


\section{Discussion}

Rhinoestrosis is a parasitic diseasethat impairs equids' welfare and performance of infested animals, resulting in significant economic losses [3].Studies on Rhinoestrus spp. infesting donkeys in Egypt are scanty [6], without any documentation of its hematological, oxidative stress and pathological features. Therefore, the present work aimed to investigate IgG and cytokines response combined with hematological profile, antioxidant defense and histopathological features developed in donkeys against Rhinoestrus spp. larvae during winter season. Some parameters were recorded previously in oestrousovis infected sheep such as blood eosinophils [19], lymphocytes and leukocytes [20], IgG [10,21] and Th2 cytokines [22]. In this study, the percent of Rhinoestrus spp existence was $50 \%$. This higher percentage was recorded in previous investigation as it could be due to the changes in the locality and hence the epidemiological environment prevailing around the sampled donkeys [2,23]. The present study indicated that the intensity and the existence of larval Rhinoestrus spp. were varied during winter season. The first larval instar (L1) was dominantly found with a higher percentage with a peak value in January 2016 then the second larval instar (L2) and the third larval instar (L3) stage larvae with a peak value in March 2016. These results could be attributed to chronobiology of rhinoestrosis in this season where the climatic temperature was suitable for emerging of adult fly and deposition of their larvae into hosts' nostrils beside that this low temperature in winter season delaying maturation of the L1 into L2 and L3 [6]. The IgG response in examined donkey's sera was estimated along the four months. Depending on IgG optical densities' values combined with the existence of larval stage, the results showed that infested and non-infested animal cases could be distinguished from each other all over the winter season as the infested cases were constantly detected. This finding might confirm previous results $[3,6]$ where the larval stage was established and the optical densities' values were increasing gradually during the winter season. This result was likeminded with activity of adult fly which began in December so, specific IgG levels were found to be sharply increased and positively interact with developing L2 and/or L3 larvae. This result was compatible to chronological generations of Rhinoestrus spp. in Egypt, as well as, the larvae might stimulate the immune response to the higher level needed to complete their nutritional requirements and growth $[4,6,24]$.
Concerning hematological study, there was a decrease in RBCs and PCV of infested donkeys besides decrease in $\mathrm{Hb}$ concentration. These results indicated that infestation by Rhinoestrus spp. induced anemia in donkeys as previously recorded [25]. The leukogram in both blood and nasal fluid of infested animals was investigated in this study. It was observed that TLC slightly increased in infested donkeys with an elevation in neutrophils\% in December and February while lymphocytes $\%$ of infested donkeys elevated during December and January. These results might be considered as an indication for both inflammatory and immune responses against infestation [24]. Some alterations in cytological parameters of nasal fluid of Rhinoestrus spp. infested donkeys during winter months were recorded in this investigation. An increase in neutrophils\% in nasal fluid of infested donkeys was recorded in February, as well as, lymphocytes\% increase in January and March. These results showed a parallelism between the inflammatory and immune cells pattern in blood and nasal fluid. As well as, it was observed that both blood and nasal fluid eosinophils $\%$ increased in this work during all winter months. These results were parallel to the previous studies where the blood eosinophilia elevated to its peak in Oestrusovis experimentally infected sheep [19]. This elevation in blood and nasal fluid eosinophilia indicated that the immune system was strongly stimulated during the infestations [24]. In the present investigation, serum protein and globulin concentrations were declined in February and March while serum albumin was decreased in February only in Rhinoestrusspp infested donkeys. These alterations might be due to blood loss and impaired appetite [25]. In the present investigation, low sodium and high potassium serum levels were observed in Rhinoestrus spp. infested donkeys. This result might be an indication for neuromuscular irritability and polarization [26,27]. As well as, serum calcium level decreased in infested animals and accompanied by oxidative stress which might lead to bone formation problem [28]. Collectively, the hematological and biochemical results in this study might indicate that the decline in serum biochemical parameters started later than the cellular alteration. Estimation of the enzymatic antioxidants activities, such as GSH-Px and SOD [29] as well as estimation of serum CAT [30] was a mean of evaluating oxidative stress. It was found that GSH -PX serum activity in infested donkeys 
decreased in January, February and March, SOD decreased in December, January and February while CAT activity decreased in all the months of the study. This data reflected the oxidative stress in Rhinoestrus spp. infested donkeys in all winter months with increasing in December and January.

The shifting of IL- 2 and TNF- $\alpha$ were measured in this study where the results revealed that IL-2 as referred to Th2 increased in the months of winter and continued to increase until March, while TNF- $\alpha$ increased in December and January only. This cellular profile suggested a Th2-type cytokine production by $\mathrm{T}$ lymphocytes [22] which indicated that the shifting was toward Th2 [31]. Clear evidence to support this hypothesis is still missing in Rhinoestrus spp. infection. Several proteins were secreted by the parasite that involved in the Th2 cytokines regulation such as IL-2 production. In addition, it was known that TNF- $\alpha$ was a main mediator which initiate an inflammatory cascade [32]. Moreover, parasitic infection provoked Th2 dominant immune responses that stimulate eosinophil and antibody switching [31].

The myiasis caused by the larvae of Rhinoestrus spp. induces severe respiratory diseases, impairs animals' health and leads to severe economic losses. The larvae localize in nasal cavities, sinuses and pharynx of the animal [33], inducing inflammation, difficult breathing, sneezing and cough. Our histopathological results revealed presence of catarrhal rhinitis, ulceration of nasal mucosa and meningioencephalitis. The latter might be associated with penetration of the ethmoid bone and the meninges by Rhinoestrus spp. [3]. Mechanical effect of oral hooks and spines of oestrids larvae besides the proteolytic enzymes found in the secretory and excretory products of these larvae were responsible for these changes in the brain [20]. Regarding to the inflammatory cells, there was a mixture of various types of cells such as macrophages, eosinophils and lymphocytes. Eosinophils are usually associated with the resistance to helminth infections [34]. The frequent recorded lesions in the sinus were disarrangement stratified epithelium, wide intercellular spaces, with loosing epithelia. Degenerative signs were prominent in some rounded cells as previously recorded [35]. This decay might be due to the effect of proteases that secreted by the larvae. These abnormal changes might lead to the diffusion of antigenic determents to be in direct contact with the locally recruited immune cells[36]. The numbers and distribution of recruited eosinophils were previously observed within the mucous membrane and sub mucosa of naturally infected sheep [37]. These recruitment process might be resist the parasitic larval populations and sustain the hypersensitivity reaction at the site of tissue damage during infection [36].

\section{Conclusion}

Finally, it could be concluded that the infestation by Rhinoestrus spp. might affect the health conditions leading to anemia and electrolytes disturbance. Specific IgG levels were found to be sharply increased and positively interact with developing L2 and/or L3 larvae where it stimulated the immune response. In addition, polarization of the immune response was shifted towards Th2 cytokines by Rhinoestrus spp. Down regulated or altered protective Th1 cytokine responses. The histopathological picture reflected the blood and nasal fluid cytological picture results as there was a picture of inflammation such as inflammatory cells elevation, lymphocytes infiltration and inflammation of meninges and cerebral cortex. The current results also confirmed that infestation by Rhinoestrus spp. could lead to oxidative stress and inflammation of central nervous system which attributed to the high irritability. This might indicate the risk of the infestation with Rhinoestrus spp. on the vital and immunological process in donkeys. Rhinoestrus spp. infection was linked with oxidative status, particularly during the winter period when energetic needs were high; hence suggesting that overload while dealing with an infestation could exaggerate oxidative stress.

\section{Conflict of Interests}

The authors declare that they have no conflict of interests.

\section{References}

1. Milillo, P., Traversa, D., Elia, G. and Otranto, D. (2010) Analysis of somatic and salivary gland antigens of third stage larvae of Rhinoestrus spp. (Diptera, Oestridae). Exp. Parasitol. 124, 361-364.

2. Otranto, D., Colwell, D.D., Milillo, P., Marco, V.D., Paradies, P. and Napoli, C. (2004) Report in Europe of nasal myiasis by Rhinoestrus spp. in horses and donkeys: Seasonal patterns and taxonomical consideration. Vet. Parasitol., 122, 79-88.

3. Ramadan, M.Y., Abd El-Mageid, A.D. and 
Abdelwahab, M.G. (2013) Ecological and immunological studies on Rhinoestruspurpureus infecting donkeys in Egypt and its control with doramectin and ivermectin. Nat. Sci., 11 (9), 96102.

4. Silva, B.F., Bassetto, C.C. and Amarante, A.F.T. (2012) Immune responses in sheep naturally infected with Oestrusovis (Diptera: Oestridae) and gastrointestinal nematodes. Vet. Parasitol., 190, $120-126$.

5. Traversa, D. and Otranto, D. (2006) A new approach for the diagnosis of animals: The example of horse nasal myiasis. Vet. Parasitol., 141, 186- 190.

6. Hilali, M.A., Mahdy, O.A. and Attia, M.M. (2015) Monthly variations of Rhinoestrus spp. (Diptera: Oestridae) larvae infesting donkeys in Egypt: Morphological and molecular identification of third stage larvae. J.A.R., 6, 1015-1021.

7. Attia, M. (2014) Studies on Rhinoestrus spp. (Diptera: Oestridae) infesting donkeys in Egypt. Ph. D Thesis, Parasitol. Depart., Fac. Vet. Med., Cairo Univ., Egypt.

8. Zhang, Y., Wang, Q., Xie, Y., Wang, Z., Li, D., Ma, L., Pang, X., Yu, W. and Zhong, N. (2014) The normative value of inflammatory cells in the nasal perfusate of Chinese adults: a pilot study. J. Thorac. Dis., 6 (7), 905-912.

9. Zayed, A.A., Abdel-Shafy, S. and Rabab M. ElKhateeb (2008) Surface Ultrastructure of Posterior Abdominal Spiracles of Third Instars of Nasal Bots of Cephalopinatitillator, Oestrusovis and Rhinoestruspurpureus (Diptera :Oestridae) infesting camels, sheep and donkeys in Egypt. Res. J. Parasitol., 3 (1), 1-11.

10. Angulo-Valadez, C.E., Scala,A., Grisez, C., Prevot, F., Bergeaud, J.P., Carta, A., CepedaPalacios, R., Ascencio,F., Terefe, G., Dorchies,Ph. and Jacquiet,Ph. (2008) Specific IgG antibody responses in Oestrusovis L. (Diptera: Oestridae) infected sheep: associations with intensity of infection and larval development. Vet. Parasitol., 155, 257-263.

11. Tabouret, G., Prevot, F., Bergeaud, J.P., Dorchies, Ph. and Jacquiet, P. (2001) Oestrusovis (Diptera: Oestridae): Sheep humoral immune response to purified excreted/secreted salivary gland $28 \mathrm{KDa}$ antigen complex from second and third instar larvae. Vet. Parasitol., 101, 53- 66.

12. Lowry, O.H., Rosebrough, N.J., Farr, A.B. and
Randall, R.J. (1951) Protein measurement with the folin-phenol reagent. J. Biol. Chem., 193, 265-275.

13. Schalm, O.W., Jain, N.C. and Caroll, E.J. (1975) Textbook of Veterinary Haematology and Edition, Published by Lea and Febiger; Philadelphia, 129-250.

14. Ghaffar, A., Ashraf, S., Hussain, R., Hussain, T., Shafique, M., Noreen, S. and Aslam S. (2014) Clinicohematological disparities induced by triazophos (organophosphate) in Japanese quail. Pakistan Vet. J., 34, 257-259.

15. Cannon, D.C., Olitzky, I. and Inkpen, J.A. (1974) In clinical chemistry principles and techniques of determination of total protein. $2^{\text {nd }}$ ed. Harper and Rowpubl; London, England.

16. Doumas, B., Watson, W. and Biggs, M. (1971) Albumin standards and the measurement of serum albumin with bromocresyl green. Clin. Chim. Acta., 31, 87-96.

17. Bancroft, J.D., Layton, C. and Suvarna, S.K. (2013) Bancroft's theory and practice of histological techniques. $7^{\text {th }} \mathrm{Ed}$. Churchill Livingstone, Elsevier; Netherland.

18. Petrie, A. and Watson, P. (1999) Statistics for veterinary and animal science. 1st Ed. The Blackwell Science Ltd; U.K. 90-99 p

19. Yacob, H.T., Jacquiet, Ph., Prevot, F., Bergeaud, J.P., Bleuart, C., Dorchies, Ph. and Hoste, H. (2004) Examination of the migration of first instar larvae of the parasite Oestrusovis (Linné 1761) [Diptera: Oestridae] in the upper respiratory tract of artificially infected lambs and daily measurements of the kinetics of blood eosinophilia and mucosal inflammatory response associated with repeated infection. Vet. Parasitol., 126, 339-347.

20. Tabouret, G., Bret-Bennis, L., Dorchies, P. and Jacquiet, P. (2003a) Serine protease activity in excretory-secretory products of Oestrusovis (Diptera: Oestridae) larvae. Vet. Parasitol., 114, 305-314.

21. Angulo-Valadez, C.E., Cepeda-Palacios, R., Ascencio, F., Jacquiet, Ph., Dorchies, Ph., Ramirez-Orduna, J.M. and Lopez, M.A. (2009) $\mathrm{IgG}$ antibody response against salivary gland antigens from Oestrusovis (Diptera: Oestridae) in experimentally and naturally infected goats. Vet. Parasitol., 161, 356-359.

Egypt. J. Vet. Sci. Vol. 48, No.2 (2017) 
22. Tabouret, G., Lacroux, C., Andreoletti, O., Bergeaud, J.P., Hailu-Tolosa,Y., Hoste, H., Prevot, F., Grisez, C., Dorchies, Ph. and. Jacquiet, $\mathrm{Ph}$. (2003b) Cellular and humoral local immune responses in sheep experimentally infected with Oestrusovis (Diptera: Oestridae). Vet. Res., 34, 231-241.

23. Getachew, M., Trawford, A., Feseha, G. and Reid, S. (2010) Gastrointestinal parasites of working donkeys of Ethiopia. Trop. Anim. Health Prod., 42 (1), 27-33.

24. Angulo-Valadez, C.E., Ascencio, F., Jacquiet,P., Dorchies, P. and Cepeda-Palacios R. (2011) Sheep and goat immune responses to nose bot infestation: a review. Med. Vet. Entomol., 25, 117-125.

25. Yacob, H.T., Basazinew, B.K. and Basu, A.K. (2008) Experimental concurrent infection of Afar breed goats with Oestrusovis (L1) and Haemonchuscontortus (L3): Interaction between parasite populations, changes in parasitological and basic haematological parameters. Exp. Parasitol., 120, 180-184.

26. Song, Y., Rohat, M., Amr, N.R., Ahmed, M.S.I., David, M., Ara,T., Jongyoon, H. and Samuel, J.L. (2011). Electrochemical activation and inhibition of neuromuscular systems through modulation of ion concentrations with ion-selective membranes. NAT. MAT., 10, 980-986.

27. Sigel, A., Sigel, H. and Sigel, R.K.O. (2013) Metal ions in life sciences: interrelations between essential 29 metal ions and human diseases. Springer Science+Business Media Dordrecht.

28. Levine, B. S., Rodríguez, M. and Felsenfeld A.J. (2014) Serum calcium and bone: effect of PTH, phosphate, vitamin D and uremia. Nefrologia., 34, 658- 669 .

29. Salar-Amoli, J., Hejazy, M. and Esfahani, A.T. (2009) Comparison between some oxidative stress biomarkers values in serum and plasma of clinically healthy adult camels (Camelusdromedarius) in Iran. Vet. Res. Commun., 33, 849-854.

30. Saleh, M.A., Mahran, O.M. and Al-Salahy, B.M. (2011) Circulating oxidative stress status in dromedary camels infested with sarcoptic mange. Vet. Res. Commun., 35 (1), 35-45.

31. Abo-Aziza, F.A.M., Hendawy, S.H.M., E1 Namaky, A.H. and Ashry, H.M. (2017) Th1/
Th2 balance and humoral immune response to potential antigens as early diagnostic method of equine Strongylus nematode infection. Vet. World, 10 (6), 679-687.

32. Baudena, M.A. (2003) Equine immunity to cyathostome infections. Ph. D Thesis, Depart. Pathobiol. Sci., Louisiana State Univ., USA.

33. Gunalan, S., Kamaliah, G., Wan, S., Rozita, A.R., Rugayah, M., Osman, M.A., Nabijah, D. and Shah, A. (2011) Sheep Oestrosis (Oestrus Ovis, Diptera: Oestridae) In Damara Crossbred Sheep. Malaysian J. Vet. Res., 2 (2), 41-49.

34. Shakya, K.P., Miller, J.E., Lomax, L.G., and Burnett D.D. (2011) Evaluation of immune response to artificial infections of Haemonchuscontortus in Gulf Coast Native compared with Suffolk lambs. Vet. Parasitol., 181, 239-247.

35. Angulo-Valadez, C.E., Philip, J., CepedaPalaciosc, R., Philippe, J. and Philippe, D. (2010) Nasal bots a fascinating world. Vet. Parasitol., 174, 19-25.

36. Dorchies, P., Tabouret,G.,Hoste,H., and JacquietP. (2006)Oestrinae host-parasite interactions. In: The Oestrid Flies. Colwell, D.D., M.J.R. Hall, and P.J. Scholl (Ed.). CABI Publishing; England. $359 \mathrm{P}$.

37. Nguyen Van Khanh, N.V., Bourge, N., Concordet, D. and Dorchies, Ph. (1996) Recherche des mastocytes et des éosinophiles de la muqueuserespiratoire chez le mouton infesténaturellement par Oestrusovis (Linné 1761). Parasite., 3, 217-221.

(Received 23/ 8/ 2017; accepted 15/9/2017)

Egypt. J. Vet. Sci. Vol. 48, No.2 (2017) 


\title{
التغيرات الإكلينيكية النسيجية المرضية والمناعية في الحمير المصرية المصابة بالرينو استروس الإنثاء فصل الثُّتاء
}

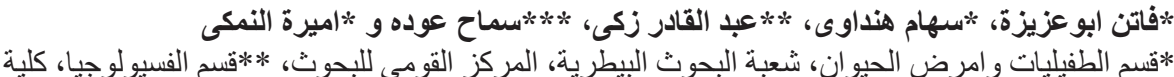
الطب البيطري، جامعة القاهرة و***قنم الباتولوجيا، كلية الطب البيطرى، جامعة الإسكندرية، ادفينا، مصر.

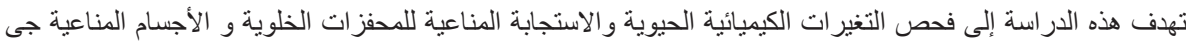

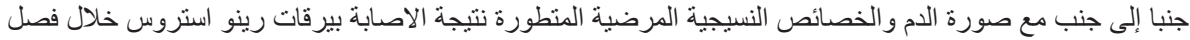

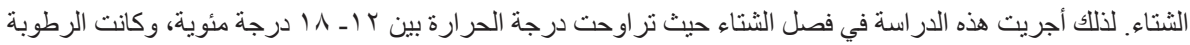

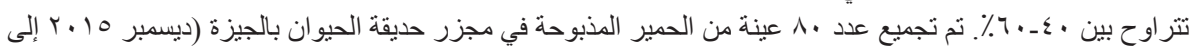

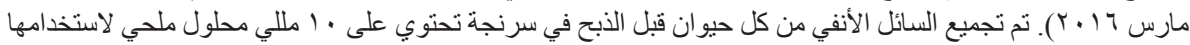

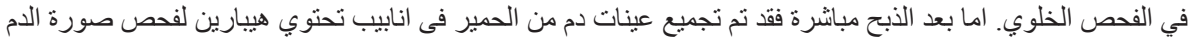

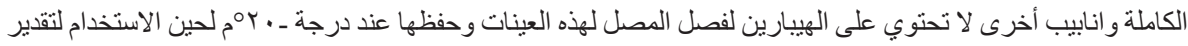

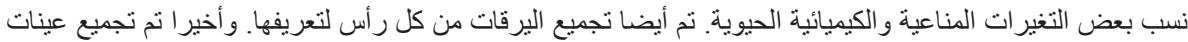

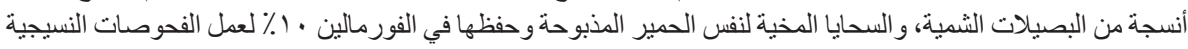

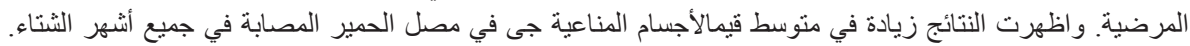

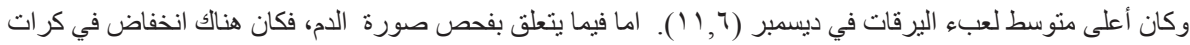

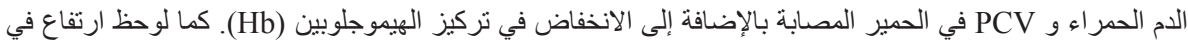

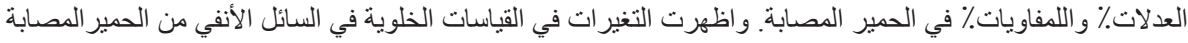

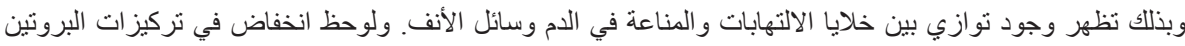

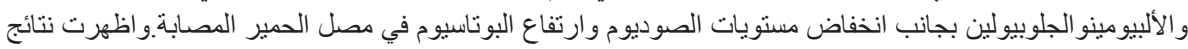

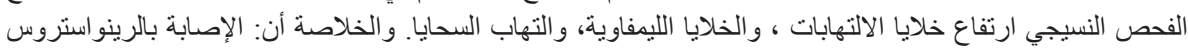

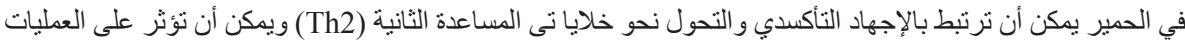
الحيوية والمناعية. الكلمات الدالة: رينو استروس، الكيميائية الحيوية، المحفز ات الخلوية، مضادات الأكسدة، الحمير.
\end{abstract}

